\title{
Bacteriological Study of Fish Samples Collected from Different Markets in Some Egyptian Governorates and Antimicrobial Sensitivity of Isolates
}

\author{
Elham I. Atwa* \\ Hafr Al Batin University, College of Science and Arts - Al Khafji, \\ Biology Department \\ *Corresponding author
}

\section{A B S T R A C T}

A total of (80) samples of living diseased cultured Tilapia fish (Oreochromusniloticus), were collected from different fish farms in Egypt (Behera and Kafr El-Sheikh) which

\section{Keywords}

Haemorrhages,

Fluorescens,

Norfloxacin,

Bacteria,

Fish,

Epidermidis

Article Info

Accepted:

26 April 2017

Available Online:

10 May 2017 showed the clinical signs of loss of scales from some areas of the skin, excessive mucus all over the body surfaces with petechial haemorrhages over the dorsal musculature, large necrotic lesions extending all over the body and darkness of skin. Differentiation and characterization of various isolates was based on their growth characteristics on specific culture media (biochemical and gram staining reactions). The following human pathogenic bacteria were isolated Staph. aureus, Staph. epidermidis, Staph. Saprophytics, Streptococcus spp., E. coli, Salmonella, P. aeruginosa, P. fluorescens, and Enterobacteriaceae from skin with the incidence of $12.5 \%, 23.8 \%, 31.3 \%, 10 \%, 25 \%$, $7.5 \%, 22.5 \%, 20 \%$, and $18.8 \%$ respectively, but from muscle with the incidence of $7.5 \%$, $7.5 \%, 12.5 \%, 8.8 \%, 22.5 \%, 5 \%, 20 \%, 18.8 \%$, and $16.3 \%$ respectively. On the other hand these bacteria isolated from intestine with the incidence of $8.8 \%, 7.5 \%, 12.5 \%, 13.8 \%$, $25 \%, 8.8 \%, 17.5 \%, 15 \%$, and $16.3 \%$ respectively, while from liver with incidence of $15 \%$, $12.5 \%, 16.3 \%, 15 \%, 35 \%, 6.3 \%, 25 \%, 23.8 \%$, and $15 \%$ respectively. In vitro sensitivity test indicated that, the most prevalent bacteria isolated from examined fish samples were sensitive to enrofloxacin, norfloxacin, ciprofloxacin and kanamycin. Most of these strains were highly resistant to erythromycin and a moxycillin. PCR panel could help for rapid diagnoses to determine the causative agents from fish samples, Staph. aureus coagulase gene and variable fragments for 16SrRNA genes from the extracted DNA at 228bp.

\section{Introduction}

Fish and fish products have long been used as a major food component for humans and animals. Fishes are known to be enriched by high nutritional components and concentrated source of energy, in addition to their high palatability and good digestibility (Mead et al., 1986; Mol et al., 2007; Dinakaran et al., 2010; Kawarazuka, 2010).

Fish is a perishable protein food, when fish is stored at $<10^{\circ}$, it remains for about 40 hours before it begins to spoil. Freezing does not prevent spoilage of fish because of autolytic activities and chemical changes occurring in fish after harvest (Huss et al., 1974, and Jay Jm modern food microbiology, 1992).

The degeneration of fish is accelerated by microorganism associated with aquatic environment as well as contaminated during post -harvest handling, when fish dies microorganisms on the surface as well as gut 
and gills begins to utilize the fish protein and food nutrient resulting in loss of nutritional value (Ames,1992). Microbial activities create undesirable changes like off-flavors, texture and appearance (Jhonstone et al., 1994).

Fish disease due to bacterial infection are considered one of the major problems in aquaculture which lead to heavy losses (Austin and Allen Austin 1985 and Austin and Austin, 1999), causing a great drop in fish production and industry. Most of the bacteria associated with these diseases are naturally saprophytic organism and widely distributed in the aquatic environment (Frerichs and Handrie, 1985).

A variety of fishes consumed regularly are prone to pathogenic spoilage especially by Vibrio spp., Shigella spp, Salmonella spp., streptococci, Staphylococci, Coliforms, Listeria spp., Clostridium spp. (Rahman et al., 2012) which may get entry into the fish from their habitat or during the fish transportation and storage (Frazier and Westhoff, 1995; Eze et al., 2010). A number of reports suggested that the consumption of the microbiologically spoiled seafoods might be responsible for food-borne diseases like diarrhea, salmonellosis, shigellosis, cholera and even some neurological diseases by an array of viruses, bacteria, fungi and parasites (Snowdon et al., 1989; Starutch, 1991; Karunasagar et al., 1994; Cray and Moon, 1995; Wallace et al., 1999; WHO, 2012).

However fish are susceptible to a wide variety of bacterial pathogens, most of which are capable of causing disease and are considered by some to be saprophytic in nature (Lipp and Ross, 1997). The microbiological diversity of fresh fish muscle depends on the fishing grounds and environmental factors around it (Cahill, 1990). It has been suggested that the type of micro-organisms that are found associated with particular fish depends on its habitat (Claucas and Ward, 1996). The bacterial pathogens associated with fish have been classified as indigenous and nonindigenous (Kvenberg, 1991). The nonindigenous contaminate the fish or the habitat one way or the other and examples include Escherichia coli, Clostridium botulinum, Shigella dysenteriae, Staphylococcus aureus, Listeria monocytogens and Salmonella. The indigenous bacterial pathogens are found naturally living in the fish $\mathrm{s}$ habitat for example Vibrio species and Aeromonas species (Rodricks, 1991). The bacteria from fish only become pathogens when fish are physiologically unbalanced, nutritionally deficient, or there are other stressors, i.e., poor water quality, overstocking, which allow opportunistic bacterial infections to prevail (Austin, 2011). Pathogenic and potentially pathogenic bacteria associated with fish and shellfish include Mycobacteium, Streptococcus spp., Vibrio spp., Aeromonas spp., Salmonella spp. and others (Lipp and Ross, 1997).

Staphylococcus, Escherichia coli, Pseudomonas, Shigella and Salmonella, were the common pathogenic bacteria found associated with fish from the ponds associated with integrated farming systems. Their presence was attributed to the contamination of the fish ponds by animal waste (Abdelhamid et al., 2006). The isolation of Salmonella, Shigella and E. coli from the fish samples indicates faecal contamination of the ponds resulting from the livestock manure that they add to the fish ponds as feed. The isolation of Salmonella, Shigella, and E. coli indicate faecal and environmental pollution (Yagoub, 2009). Coliforms such as E. coli are usually present where there has been faecal contamination from warm blooded animals (Chao et al., 2003). E. coli is recognized as the reliable indicator of faecal contamination in small numbers and in large numbers, it is 
an indicator of mishandling (Eze et al., 2011). $E$. coli is the only species in the coliform group that is found in the human intestinal tract and in the other warm blooded animals as a commensal and is subsequently excreted in large quantities in faeces (Geldreich, 1983).

One of the risks involved in livestock integrated fish farming is possible transfer of pathogens between livestock and humans. Previous research has shown that, different kinds of livestock manure are contaminated with pathogenic bacteria such as Salmonella, Shigella, Pseudomonas, Vibrio, Streptococcus, and E. coli species (Abdelhamid et al., 2006). Rate of bacterial spoilage is dependent on the initial microbial load, ambient temperature and improper handling. Therefore, proper storage critical in maintaining a high standard of safety when processing fish. (Jay Jm modern food microbiology, 1992).

The transmission of these pathogens to people can be through improperly cooked food or the handling of the fish. There have been great economic losses reported due to food borne illness such as dysentery and diarrhea resulting from consumption of contaminated fish and such can be a problem to the immune compromised, children and elderly people.

The aim of the present study is to prove the demonstration, isolation and identification of of human pathogenic bacteria from the skin, muscle, intestines and liver of living diseased fish samples.

Besides, susceptibility of most predominant isolates to chemotherapeutic agents as an aid to overcome this problem and reduce losses. Also, using polymerase chain reaction (PCR) test to substitute the conventional cultural methods and rapid diagnosis of Staph. aureus directly from fish samples.

\section{Materials and Methods}

\section{Samples}

A total of (80) samples of living diseased Tilapia fish (Oreochromus niloticus), were collected from different fish farms in Egypt (Behera and Kafr El-Sheikh), during the period from May 2014 till February 2015. The collected fish subjected to gross clinical examination according to the method described by (Amlacher 1970), showed the clinical signs of Loss of scales from some areas of the skin, excessive mucus all over the body surfaces with petechial haemorrhages over the dorsal musculature. Large necrotic lesions extending all over the body with tail rot. Skin showed superficial ulcers, and darkness of skin (Fig. 1). The fish samples were transferred a aseptically to laboratory of microbiology without delay in large sterile jars containing water.

The surface of fish bodies were disinfected by alcohol (70\%), then dissected under antiseptic conditions. The freshly dead collected samples of fishes were subjected to post mortem examination (PM) before the bacteriological examination according to (Lucky 1977, and Conroy and Herman 1981).The post mortem examination revealed of generalized septicemia and enlargement in most internal organs especially kidney, liver, intestinal tract, spleen and severe distension of gall bladder with bile secretion, congested gills and gall bladder (Fig. 2).

\section{Bacteriological examination}

Specimens of fish obtained from skin, muscle, intestine and liver were inoculated directly in nutrient broth and incubated at $37^{\circ} \mathrm{C}$ for 6 hours. Loopful from each broth culture were inoculated directly onto nutrient agar, blood agar, Macconkey's agar, bile salt lactose agar, Salmonella. Shegilla agar, Mannitol Salt agar, 
Baird parker's agar media for isolation of S. aureus,, Eosin Methylene blue agar media for isolation of $E$. coli and Enterobacteriacae family. The plates were incubated at $37^{\circ} \mathrm{C}$ for 24-48 hours. Suspected colonies onto the surface of these media were identified by studying characters of the colonies as well as Gram's stain, then identified morphologically according to the method described by (Kloss and Schleifer1986, Barrow and Feltham 1993 and Austin and Austin 1999).

One single colony showed typical colonial appearance and morphological characters was picked up and streaked into semisolid agar media and incubated at $37^{\circ} \mathrm{C}$ for 24 hours to obtain pure culture, for further identification. The pure colonies were biochemically identified according to (Cruickshank et al., 1975, Koneman et al., 1992, Quinn et al., 2002). The Gram negative bacteria included Enterobacteriacae family were biochemically identified according to (Morrison et al., 1981 and Krieg and Holt 1984).

\section{Antibiotic sensitivity tests (Antibiogram)}

The sensitivity of bacterial isolates to different antimicrobial agents were investigated using the disc diffusion method as described by (Lennette et al.,1980, and Finegold and Martin 1982) to detect the drug of choice against different isolated bacteria for trials of treatment. The results were interpretated according to (Koneman et al., 1992).

\section{Extraction of Staph. aureus DNA (Løvseth and BerdalK 2004)}

Isolated Staph. aureus strains were incubated overnight in $10 \mathrm{ml}$ brain heart infusion broth (Oxoid), centrifuged at $(5000 \mathrm{rpm}$, for 15 min) and resuspended in $0.5 \mathrm{ml}$ TE buffer (10 mMTris, 1 mM EDTA - pH 8). Total cellular DNA was extracted using Qiagen DNA extraction kit (Qiagen, Germany) according to manufacturer's protocol for gram-positive bacteria. The extracted DNA from samples was dissolved in $25 \mu \mathrm{l}$ sterile distilled water and stored at $-20^{\circ} \mathrm{C}$ until further use.

Multiplex PCR was performed on the extracted DNA from samples (part C) to detect coagulase (coa) and 16SrRNA genes (Hookey et al., 1998 and Løvseth and BerdalK 2004).

Primers for Staph. aureus coagulase (coa) and 16SrRNA genes

Specific oligonuclotide multiplex primer assay (synthesized by MWG-Biotech AG, Holle \& Huttner GmbH, Germany), for rapid diagnosis of Staph. aureus coagulase (coa) and 16SrRNA genes. The forward primer for coagulase (coa) was 5'ATAGAGATGCTGGT -3', while the reverse primer was 5`-GCTTCCGATTGTTCG -3` (Hookey et al., 1998). While the forward primer for 16SrRNA gene was 5'GTAGGTGGCAAGCG -3', while the reverse primer was 5'-CGCACATCAGCGTC-3' (Løvseth and BerdalK 2004).

\section{Staph. aureus DNA amplification by PCR}

The PCR was performed (Hookey et al., 1998 and Løvseth and BerdalK 2004) in a touchdown thermocycler in a total reaction volume of $30 \mathrm{ul}$ containing $2.5 \mu \mathrm{l}$ of extracted DNA, $1 \mu \mathrm{l}$ of each primer $(10 \mathrm{pmol} / \mu \mathrm{l}), 0.6 \mu \mathrm{l}$ of deoxynucleoside triphosphate (10 $\mathrm{mmol} / \mathrm{L}), 3 \mu \mathrm{l}$ of $10 \mathrm{X}$ thermophilic buffer (Promega), $1.8 \mu \mathrm{l}$ of $\mathrm{MgCl} 2$ ( $25 \mathrm{mmol} / \mathrm{L}), 0.1$ $\mu \mathrm{l}$ of Taq DNA polymerase $(5 \mathrm{U} / \mu \mathrm{l})$, and complete the reaction volume using distilled water in $0.2-\mathrm{ml}$ reaction tube. The presence of PCR products was determined by electrophoresis of $10 \mu \mathrm{l}$ of the DNA product in a $1.5 \%$ agarose gel with $1 \mathrm{X}$ TAE buffer (40 mMTris-HCl, $1 \mathrm{mM}$ EDTA/L, $1.14 \mathrm{ml} / \mathrm{L}$ 
glacial acetic acid, $\mathrm{pH} 7.8$ ) at a voltage of 4 volts $/ \mathrm{cm}$ and stained with $0.5 \mathrm{mg} / \mathrm{ml}$ ethidium bromide and the Fluorescent bands were visualized with a UV transilluminator and photographed. A 100-bp DNA ladder (Gibco BRL) was used as a molecular marker. Amplification was obtained with 35 cycles. Each cycle involved initial denaturation at $93^{\circ} \mathrm{C}$ for 3 minutes, denaturation at $92^{\circ} \mathrm{C}$ for 1 minutes, annealing at $52^{\circ} \mathrm{C}$ for 1 minutes, and extension at $72^{\circ} \mathrm{C}$ for 1 minutes. The final extension was performed at $72^{\circ} \mathrm{C}$ for 7 minutes.

The presence of PCR products was determined by electrophoresis of $10 \mu \mathrm{l}$ of the DNA product in a $1.5 \%$ agarose gel with $1 \mathrm{X}$ TAE buffer $(40$ mMTris-HCl, $1 \mathrm{mM}$ EDTA/L, $1.14 \mathrm{ml} / \mathrm{L}$ glacial acetic acid, $\mathrm{pH}$ 7.8) at a voltage of 4 volts $/ \mathrm{cm}$ and stained with $0.5 \mathrm{mg} / \mathrm{ml}$ ethidium bromide and the Fluorescent bands were visualized with a UV transilluminator and photographed. A 100-bp DNA ladder (Gibco BRL) was used as a molecular marker.

\section{Results and Discussion}

Results in table 1 shows the total bacterial isolates from different site of (80 skin, 80 muscle, 80 intestine and 80 liver) of examined naturally infected fishes which were $(30.4 \%$, $21.1 \%, 22.2 \%$ and $26.2 \%$ respectively). The prevalence of bacterial isolates from the different examined naturally infected fishes is illustrated in table 1 also. The result revealed that isolation rate was (10.9) for Staph. aureus, (12.8) for Staph. epidermidis, (18.1) for Staph. Saprophytics, (11.9) for Streptococcus spp., (22.8) for E. coli, (6.9) for Salmonella, (21.3) for P. aeruginosa, (19.4) for $P$. fluorescens and (16.6) for Enterobacteriaceae.

Table 2 showed the in vitro sensitivity of the most prevalent bacteria isolated from collected fish samples were done against (14) chemotherapeutic agents. Most tested strains of Staph. aureus, Staph. epidermidis, Staph. Saprophytics, Streptococcus spp., E. coli, Salmonella, P. aeruginosa, P. fluorescens, and Enterobacteriaceae were sensitive to enrofloxacin, norfloxacin, ciprofloxacin and kanamycin. Most of these strains were highly resistant to erythromycin and amoxicillin.

Figure 3 showed three diseased fish samples representative for positive Staph. aureus isolates, were selected and subjected to PCR analysis. The specificity of the oligonucleotide primer was confrimed by the positive amplification of 228bp fragments for Staph. aureus coagulase (coa) and variable fragments for 16SrRNA genes from the extracted DNA of Staph. aureus.

Aquaculture products can harbor pathogenic bacteria which are part of the natural microflora of the environment. Bacterial pathogens associated with fish can be transmitted to human beings from fish used as food or by handling the fish causing human diseases. The role of bacteria varies from their effect as primary pathogen to that of secondary invader in the presence of other disease agents; they may also serve as a stress factor and predispose fish to other diseases (Badran and Eissa, 1991).

The isolation of enteric bacteria in fish serves as indicator organisms of faecal contamination and or water pollution. Their presence also represents a potential hazard to humans. Generally, the presence of coliform and faecal coliform is not the normal flora of bacteria in fish (Mandal et al., 2009). This is reflecting the contamination of fish habitat with the human and animal faeces.

Staphylococcus spp. It is associated with food poisoning, produced toxin, which makes man sick, usually associated with the nausea, vomiting and diarrhea after eating the staphylococci infected food (O'connell, 2002). 
In the present work, we spot light on the clinical picture and PM lesions of the most predominant bacterial pathogens affecting Oreochromus niloticus fishes. Moreover, isolation and identification of these bacterial infections by both biochemical traditional methods serological as well as by PCR, Concerning the clinical signs and Postmortem (PM) lesions of examined Oreochromus niloticus fish. In regard to the results of clinical signs and PM lesions of bacterial naturally infected fishes, our results were similar to the findings recorded by (Post 1987, Badran and Eissa, 1991and Austin and Austin, 1999), where they mentioned that bacterial infection causes generalized septicemia and enlargement in most internal organs.

Table.1 Prevalence of bacteria isolated from skin, muscle, intestine and liver of collected fish samples

\begin{tabular}{|c|c|c|c|c|c|c|c|c|c|c|}
\hline \multirow{3}{*}{ Bacterial isolates } & \multicolumn{10}{|c|}{ Site of isolation } \\
\hline & \multicolumn{2}{|c|}{ Skin (80) } & \multicolumn{2}{|c|}{ Muscle(80) } & \multicolumn{2}{|c|}{$\begin{array}{c}\text { Intestine }(80 \\
)\end{array}$} & \multicolumn{2}{|c|}{ Liver(80) } & \multicolumn{2}{|c|}{ Total } \\
\hline & No. & $\%^{*}$ & No. & $\%^{*}$ & No. & $\%^{*}$ & No & $\%^{*}$ & No & $\%^{* *}$ \\
\hline Staph. aureus & 10 & 12.5 & 6 & 7.5 & 7 & 8.8 & 12 & 15 & 35 & 10.9 \\
\hline Staph. epidermidis & 19 & 23.8 & 6 & 7.5 & 6 & 7.5 & 10 & 12.5 & 41 & 12.8 \\
\hline Staph. saprophytics & 25 & 31.3 & 10 & 12.5 & 10 & 12.5 & 13 & 16.3 & 58 & 18.1 \\
\hline Streptococcus spp. & 8 & 10 & 7 & 8.8 & 11 & 13.8 & 12 & 15 & 38 & 11.9 \\
\hline E. coli & 20 & 25 & 18 & 22.5 & 20 & 25 & 15 & 35 & 73 & 22.8 \\
\hline Salmonella & 6 & 7.5 & 4 & 5 & 7 & 8.8 & 5 & 6.3 & 22 & 6.9 \\
\hline P. aeruginosa & 18 & 22.5 & 16 & 20 & 14 & 17.5 & 20 & 25 & 68 & 21.3 \\
\hline P. fluorescens & 16 & 20 & 15 & 18.8 & 12 & 15 & 19 & 23.8 & 62 & 19.4 \\
\hline Enterobacteriaceae & 15 & 18.8 & 13 & 16.3 & 13 & 16.3 & 12 & 15 & 53 & 16.6 \\
\hline $\begin{array}{c}\text { Total bacterial } \\
\text { isolates }\end{array}$ & 137 & 30.4 & 95 & 21.1 & 100 & 22.2 & $\begin{array}{c}11 \\
8\end{array}$ & 26.2 & $\begin{array}{c}45 \\
0\end{array}$ & 100 \\
\hline
\end{tabular}

$\%$ was calculated according to total number of samples (80)

$\%^{* *}$ was calculated according to the total number of samples (320)

Fig.1 Oreochromus niloticus naturally infected with bacteria showing petechial haemorrhages over the dorsal musculature. Large necrotic lesions extending all over the body

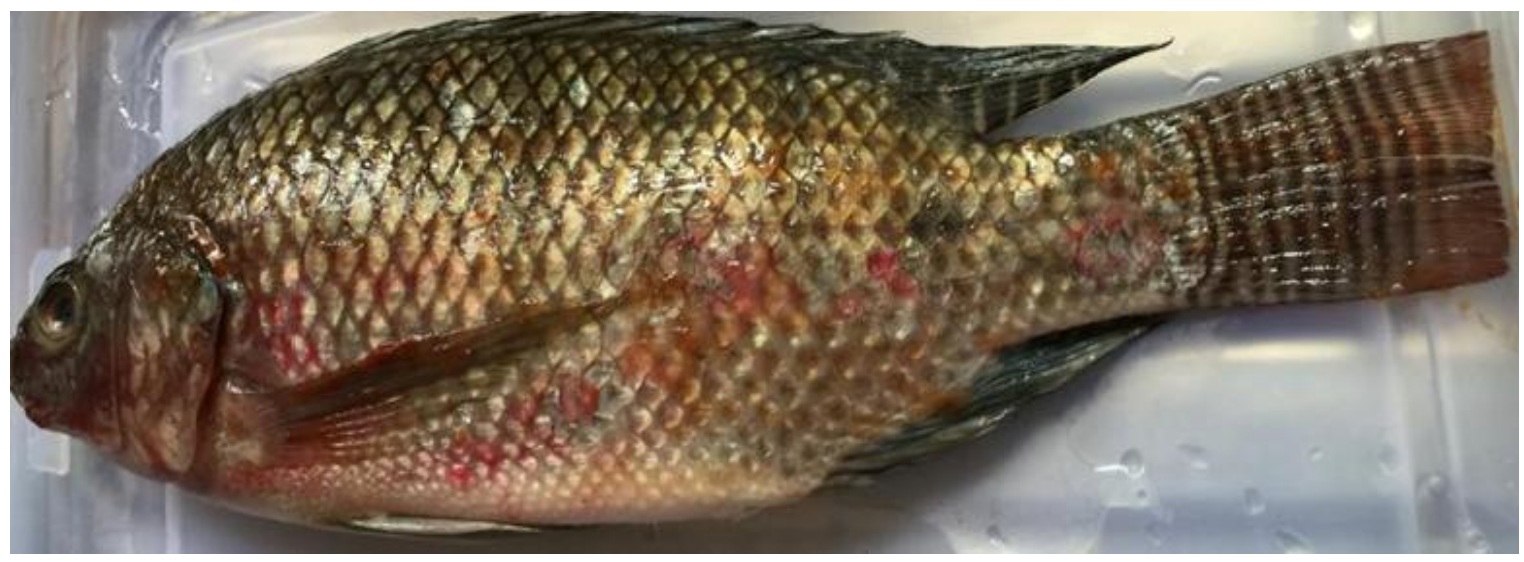


Table.2 Results of antibiogram pattern of the most prevalent bacteria Isolated from collected fish samples

\begin{tabular}{|c|c|c|c|c|c|c|c|c|c|c|c|c|c|c|c|c|c|c|}
\hline \multirow[t]{2}{*}{ Antibacterial agents } & \multicolumn{2}{|c|}{$\begin{array}{l}\text { Staph. } \\
\text { aureus }\end{array}$} & \multicolumn{2}{|c|}{$\begin{array}{l}\text { Staph. } \\
\text { epidermidis }\end{array}$} & \multicolumn{2}{|c|}{$\begin{array}{c}\text { Staph. } \\
\text { Sapro } \\
\text { phyticus }\end{array}$} & \multicolumn{2}{|c|}{ Streptococcus } & \multicolumn{2}{|c|}{ E.coli } & \multicolumn{2}{|c|}{ Salmonella } & \multicolumn{2}{|c|}{\begin{tabular}{c|}
$P$. \\
aeruginosa
\end{tabular}} & \multicolumn{2}{|c|}{$\begin{array}{c}P . \\
\text { fluorescens }\end{array}$} & \multicolumn{2}{|c|}{$\begin{array}{c}\text { Enterobacter } \\
\text { iaceae }\end{array}$} \\
\hline & S. & $\%$ & S. & $\%$ & S. & $\%$ & S. & $\%$ & S. & $\%$ & S. & $\%$ & S. & $\%$ & S. & $\%$ & S. & $\%$ \\
\hline Amoxycillin (25ug) & $6 / 15$ & 40 & $5 / 15$ & 33.3 & $2 / 15$ & 13.3 & $6 / 15$ & 40 & $0 / 15$ & 0 & $2 / 15$ & 13.3 & $1 / 15$ & 6.7 & $2 / 15$ & 13.3 & $1 / 15$ & 6.7 \\
\hline $\begin{array}{c}\text { Chloramphenicol } \\
\text { (30ug) }\end{array}$ & $6 / 15$ & 40 & $5 / 15$ & 33.3 & $7 / 15$ & 46.7 & $11 / 15$ & 73.3 & $0 / 15$ & 0 & $9 / 15$ & 60 & $9 / 15$ & 60 & $10 / 15$ & 66.7 & $2 / 15$ & 13.3 \\
\hline Ciprofloxacin (5ug) & $14 / 15$ & 93.3 & $13 / 15$ & 86.7 & $14 / 15$ & 93.3 & $13 / 15$ & 86.7 & $14 / 15$ & 93.3 & $14 / 15$ & 93.3 & $15 / 15$ & 100 & $15 / 15$ & 100 & $13 / 15$ & 86.7 \\
\hline Erythromycin (10ug) & $1 / 15$ & 6.7 & $1 / 15$ & 6.7 & $5 / 15$ & 33.3 & $3 / 15$ & 20 & $2 / 15$ & 13.3 & $2 / 15$ & 13.3 & $0 / 15$ & 0 & $1 / 15$ & 6.7 & $3 / 15$ & 20 \\
\hline Flumequine (30ug) & $11 / 15$ & 73.3 & $8 / 15$ & 53.3 & $14 / 15$ & 93.3 & $11 / 15$ & 73.3 & $1 / 15$ & 6.7 & $1 / 15$ & 6.7 & $0 / 15$ & 0 & $1 / 15$ & 6.7 & $14 / 15$ & 93.3 \\
\hline Gentamicin (10ug) & $10 / 15$ & 66.7 & $15 / 15$ & 100 & $14 / 15$ & 93.3 & $14 / 15$ & 93.3 & $13 / 15$ & 86.7 & $13 / 15$ & 86.7 & $12 / 15$ & 80 & $13 / 15$ & 86.7 & $9 / 15$ & 60 \\
\hline Norfloxacin (10ug) & $15 / 15$ & 100 & $13 / 15$ & 86.7 & $12 / 15$ & 80 & $15 / 15$ & 100 & $15 / 15$ & 100 & $15 / 15$ & 100 & $8 / 15$ & 53.3 & $2 / 15$ & 13.3 & $13 / 15$ & 86.7 \\
\hline $\begin{array}{c}\text { Polymyxin } \\
\text { (10ug) }\end{array}$ & $9 / 15$ & 60 & $12 / 15$ & 80 & $6 / 15$ & 40 & $8 / 15$ & 53.3 & $1 / 15$ & 6.7 & $1 / 15$ & 6.7 & $0 / 15$ & 0 & $2 / 15$ & 13.3 & $6 / 15$ & 40 \\
\hline $\begin{array}{l}\text { Streptomycin } \\
\text { (10ug) }\end{array}$ & $12 / 15$ & 80 & $10 / 15$ & 66.7 & $8 / 15$ & 53.3 & $5 / 15$ & 33.3 & $14 / 15$ & 93.3 & $14 / 15$ & 93.3 & $9 / 15$ & 60 & $10 / 15$ & 66.7 & $5 / 15$ & 33.3 \\
\hline $\begin{array}{c}\text { Penicillin G } \\
\text { (10ug) }\end{array}$ & $0 / 15$ & 0 & $13 / 15$ & 86.7 & $7 / 15$ & 46.7 & $9 / 15$ & 60 & $1 / 15$ & 6.7 & $1 / 15$ & 6.7 & $0 / 15$ & 0 & $1 / 15$ & 6.7 & $5 / 15$ & 33.3 \\
\hline Kanamycin (30ug) & $13 / 15$ & 86.7 & $12 / 15$ & 80 & $13 / 15$ & 86.7 & $13 / 15$ & 86.7 & $15 / 15$ & 100 & $15 / 15$ & $13 / 15$ & 86.7 & 100 & $14 / 15$ & 93.3 & $15 / 15$ & 100 \\
\hline
\end{tabular}

S: Sensitive; \%: Percentage of sensitive isolates in relation to total isolates.

Fig.2 Oreochromus niloticus naturally infected with bacteria showing generalized septicemia and enlargement in most internal organs

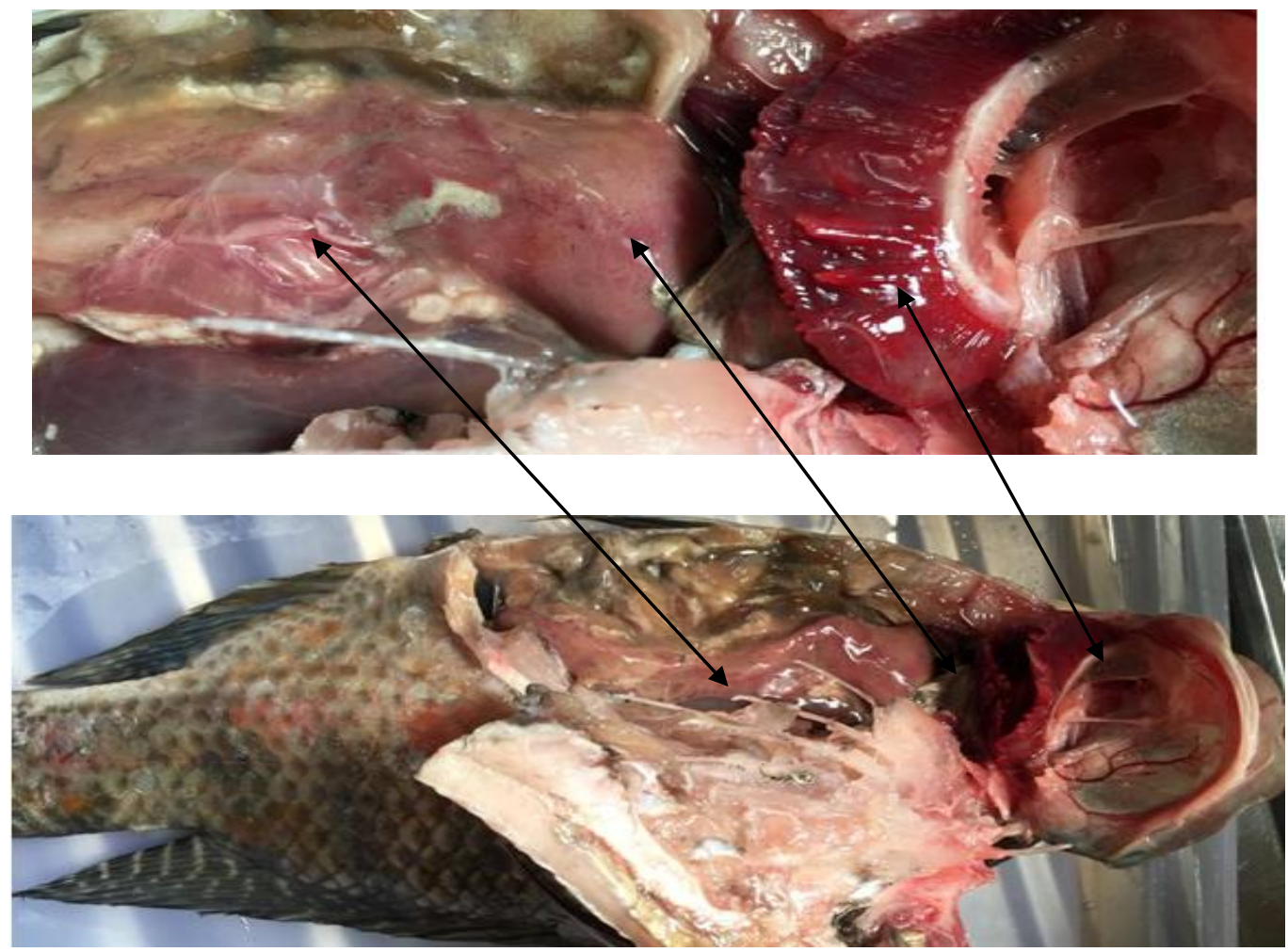


Fig.3 Electrophoresis analysis of PCR product of amplified Staph. aureus coagulase (coa) and 16SrRNA genes

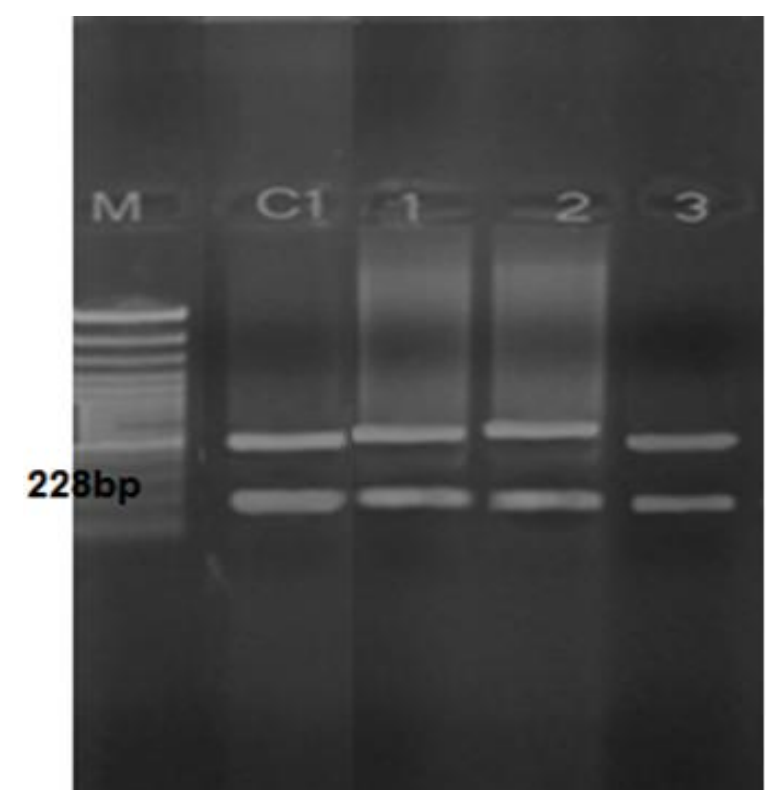

M: 100bp marker.

Lane 1, 2 and 3 indicate a positive amplification Staph. aureus coagulase (coa) at the 228bp and variable for 16SrRNA genes:

C1: Control positive for Staph. aureus coagulase (coa) and 16SrRNA genes

In regards to the Incidence of the bacterial isolates among naturally examined fishes as shown in table 1 , the most predominant isolates from skin were Staph. Saprophytics (31.3\%), E. coli (25\%), Staph. Epidermidis (23.8\%), P. aeruginosa (22.5\%), P. fluorescens (20\%), Enterobacteriaceae (18.8\%), Staph. aureus, (12.5\%), Streptococcus spp. (10\%) and Salmonella $(7.5 \%)$, while the most predominant isolates from muscle were E. coli $(22.5 \%), P$. aeruginosa (20\%), P. fluorescens (18.8\%), Enterobacteriaceae (16.3\%), Staph. Saprophytics (12.5\%), Streptococcus spp (8.8\%), Staph. aureus (7.5\%), Staph. Epidermidis (7.5\%) and Salmonella (5\%). On the other hand the most predominant isolates from intestine were $E$. coli (25\%), $P$. aeruginosa (17.5\%), Enterobacteriaceae (16.3\%), P. fluorescens (15\%), Streptococcus spp. (13.8\%), Staph. saprophytics (12.5\%), Staph. aureus (8.8\%), Salmonella (8.8\%) and Staph. epidermidis (7.5\%), but the most predominant isolates from liver were E. coli
(35\%), P. aeruginosa (25\%), P. fluorescens (23.8\%), Staph. saprophytics (16.3\%), Staph. aureus (15\%), Streptococcus spp. (15\%), Enterobacteriaceae (15\%), Staph. epidermidis (12.5\%) and Salmonella (6.3\%).

In similar studies, Escherichia coli, Pseudomonas aueriginosa, Staphylococcus aureus and Salmonella typhi were isolated from the gills, intestines, muscle and skin of Megalaspiscordyla and muscles of Priacanthushamrur from Royapuram waters in India by (Sujatha et al., 2011). This was attributed to the heavy load of sewage disposal into the seas which could act as a suitable environment for the growth and survival of the human pathogens. Members of the genus Pseudomonas are found in the soil and natural sources of water and are important phytopathogens and agents of human infections being considered opportunistic pathogens (Sujatha et al., 2011). 
This also confirms the findings of (Koutsoumanisand Nychas, 2000; GonzalezPodriguez et al., 2001; Herrera et al., 2006), who isolated similar organisms from fish and fish products. The presence of these bacterial species in fish has been reported to be of public health significance, because of their primary role as occupational hazard to fish handlers (Ibiwoye et al., 2001).

Table 2 showed the in vitro sensitivity of the most prevalent bacteria isolated from collected fish samples were done against (11) chemotherapeutic agents. Most tested strains of Staph. aureus, Staph. epidermidis, Staph. saprophytics Streptococcus spp., E. coli, Salmonella, P. aeruginosa, P. fluorescens and Enterobacteriaceae were sensitive to enrofloxacin, norfloxacin, ciprofloxacin and kanamycin. Most of these strains were highly resistant to erythromycin and amoxicillin. The data generated from this experiment are essential in the choice of most effective antimicrobial agents against fish pathogenic bacteria of fish. This results nearly agreed with those of (Zaky 2009) who arranged the antibiotic according its effect on E. coli isolated from fish, the least to high were chloramphenicol (30 mcg), ampicillin (10 mcg), penicillin $\mathrm{G}(10 \mathrm{mcg})$, streptomycin $(10 \mathrm{mcg})$ and Gentamycin (10 mcg).

Antimicrobial agents are widely used by farmers especially in the intensive culture system. Misuse of drugs and non-compliance with treatment regiments among users can cause treatment to be less effective thereby prolonging the duration of disease (Muniruzzaman and Choudhury, 2004).

The use of polymerase chain reaction (PCR), as shown in figure 3 , revealed positive amplification of Staph. aureus on 228 bp fragments for Staph. aureus coagulase (coa) and variable fragments for 16SrRNA genes from the extracted DNA of Staph. aureus on lane 1-3. These results suggest that the PCR assay could be used as an alternative method in routine diagnosis for rapid, sensitive, and specific simultaneous detection of Staph. aureus in fish samples. Our results were in agreement with those of other studies (Coton and Coton, 2005; Janda and Abbott, 2007; Olivares et al., 2008). Also, these results are agreement with the results of (Phuektes and Browning, 2001; Gillespie and Oliver, 2005; Cremonesi et al., 2006).

In conclusion, fish are susceptible to all contaminant organisms that may be found in water, post harvesting, marketing, dealing, fish handlers, this processing will result in microbiological activities leading to loss of fish meat quality so the basic principles for prevention of food borne disease and sanitation should be followed to protect the consumers against the public health hazard, the widespread presence of antibiotic resistance microorganisms should be a priority to reinforce the importance of basic hygiene for fish.

\section{References}

Abdelhamid, A.M., Gawish, M.M., Soryal, K.A. (2006): Comparative study between desert cultivated and natural fisheries of mullet fish in Egypt. IIMicrobiological concern. J. Agric. Scie., Mansoura Univ., 31: 56815687.

Ames GR (1992): The kinds and levels of postharvest losses in Africa in land fisheries. Food agriculture organization of the united nations. Rome Italy, (1992). CIFA technical paper 19 .

Amlacher, E. (1970): Textbook of fish diseases, T.E.S. Publication, NewJersey. USA, P. 117-135.

Austin, B. (2011): Taxonomy of bacterial fish pathogens. Vet. Res., 42 (1): 20.

Austin, B. and Allen- Austin, D. (1985): A review. Bacterial pathogens of fish. J. Appl. Bact., 58: 483 -506.

Austin, B. and Austin, D. A. (1999): Bacterial fish pathogens: disease of farmed and wild fish, 3rd edn (revised). SpringerPraxis series in aquaculture and fisheries. Springer-Verlag, London. 
Badran and Eissa, (1991): Studies on bacterial diseases among cultured fresh water fish

Barrow G L and Feltham R K (1993): Cowan and steel's manual for the identification of medical bacteria 3 rd ed. university press Cambridge.

Cahill, M. M. (1990): bacterial flora of fishes: are view, journal of microbial ecology.19(1):21-41.

Chao, K.K., Chao, C.C. and Chao, W.L. (2003):Suitbility of the traditional microbial indicators and their enumerating methods in the assessment of fecal pollution of subtropical freshwater environments. Journal of Microbiology Immunological Infection.36, pp 288-293.

Claucas, I.J., Ward, A.R. (1996): Post-harvest fisheries development: A guide to handling, preservation, processing and quality. Charthan, Maritime, Kent ME4 4TB, United Kingdom.

Conroy, D. A. and Herman, L. R. (1981): Text book of fish diseases. T.F.H. publ., West Sylvania.

Cray, W. C. J. and Moon, H. W. (1995): Experimental infection of calves and adult cattle with Escherichia coli O157:H7. Applied Environmental Microbiology 61(4):1586-1590.

Cruickshank R, Duguid I P, Marmion B and Swain R H (1975): Medical microbiology 12th ed. Livingstone Iowa New York.

Dinakaran, G. K., Soundarapandian, P. and Tiwary, A. K. (2010): Nutritional status of edible Palaemonid Prawn Macrobrachiumscabriculum(Heller 1862). European Journal of Applied Science 2(1): 30-36.

Eze, E. I., Echezona, B. C. and Uzodinma, E. C. (2011): Isolation and identification of pathogenic bacteria associated with frozen mackerel fish (Scomberscombrus) in a humid tropical environment. African Journal of Agricultural Research 6(7): 1918-1922.

Finegold, S. M. and Martin,W.J. (1982) :Bailey and Scott,s Diagnostic Microbiology. 6th ed. The C.V. Mosby Co., St., Lowis, Toronto, London.

Frazier, W. C. and Westhoff, D. C. (1995): Contamination, preservation, and spoilage of fish and other seafoods. In Food Microbiology, p. 243. 4th edn. New Delhi: Tata Mcgraw-Hill publishing company ltd.

Frerichs, G. N. and Handrie, M. S. (1985): Bacteria associated with disease of fish. In isolation and identification of Microorganisms of Medical and Veterinary Importance. Pp. 355- 371. Society for Applied Bacteriology.

Geldreich, E.E. (1983): Bacterial populations and indicator concepts in feces, sewage, storm water and solid wastes.In: G.Berg $(\mathrm{Ed})$, Indicators of viruses in water and food. Ann Arbor Science Publishers, Inc., Orlando, Fla.183, pp.51-97.

Gonzalez-Rodriguez MN, Sanz JJ, Santos JA, Otero A, Garcia-lopez ML (2001): Bacteriological Quality of aquaculture freshwater fish portions in prepackaged trays stored at 3 degrees C. J. Food Prot. 64 (9): 1399 - 1404.

Herrera FC, Santos JA, Otero A, Garcia-Lopez ML (2006): Occurrence of Foodborne pathogenic bacteria in retails prepackage portions of marine fish in Spain. J. Appl. Microbiol. 100(3): 527-36.

HookeyJ V, Richardson JF and Cookson B D (1998):" Molecular typing of Staphylococcus aureus based on PCR restriction fragment length polymorphism and DNA sequence analysis of the coagulase gene." J. Clin. Microbiol. 36 1083- 1089.

Huss, H.H., Pedersen, A. and D.C. cann (1974): the incidence of Clostridium botulinum in Danish trout farms. distribution in fish and their environment. measures to reduce contamination of the fish.j.of food. Tech 9:445-458. J. Fish. Dis., 4 (3): 243 258.

Ibiwoye, T.I.I., Okaeme, A.N. and Agbontale, J.J. (2001): Distribution and occurrence of bacteria Fish diseases in different culture facilities of Kainji Lake area. A 
paper presented at the 16th annual conference and silver jubilee of FISON at Maiduguri Nov. 2001. 221-226

Janda, J.M. and Abbott, S.L. (2007): 16S rRNA Gene Sequencing for Bacterial Identification in the Diagnostic Laboratory: Pluses, Perils, and Pitfalls. Journal of Clinical Microbiology, 45, 2761-2764.

Coton, E. and Coton, M. (2005): Multiplex PCR for Colony Direct Detection of GramPositive Histamine- and TyramineProducing Bacteria. Journal of Microbiological Methods.

Phuektes P, Mansell PD and Browning G F (2001): " Multiplex Polymerase Chain Reaction Assay for simultaneous detection of Staphylococcus aureus and Streptococcal causes of bovine mastitis." J. of Dairy Sci. 84 (5): 1140-1148.

Gillespie B E and Oliver SP (2005): " Simultaneous detection of mastitis pathogens Staphylococcus aureus Streptococcus uberis and Streptococcus agalactiae by Multiplex Real Time Polymerase Chain Reaction." J. Dairy Sci. October 88 (10) : 3510-3518.

CremonesiP,Castiglioni B, Malferrari G, Biunno I, Vimercati C, MoroniP,Morandi S, and Luzzana M (2006): " Technical note: Improved method for rapid DNA extraction of mastitis pathogens directly from milk." J. Dairy Sci. January. 89 (1): 163-169.

Jay, J.m. (1992): modern food microbiology 4th edition.chapman\& hall; London, 199-233.

Jhonstone, W.A., Nicholason, F. J. Roger, A. and G.D. stroud (1994): Freezing and refrigerate storage in fisheries. Technical paper No.334Rome. FAO143pp.

Karunasagar, I., Pai, R., Malathi, G. R., and Karunasagar, I. 1994. Mass mortality of Penaeus monodon larvae due to antibiotic resistant Vibrio harveyiinfection. Aquaculture 128: 203-209.

Kawarazuka, N. (2010): The contribution of fish intake, agriculture, and small scale fisheries to improve nutrition: aliterature review. Report paper of World Fish Center. Penang, Malaysia.

Kloss W E and Schleifer K H (1986):Bergey's manual of systematic bacteriology. Vol. II. Williams and Wikins London

Koneman, K. W. ; Allen, S. D. ; Dowell, V. R. and Sommers, H. M. (1992): "Color atlas and text book of diagnostic Microbiology."2nded, J. B. Lippicott Co., London.

Koutsoumanis K, Nychas GJ (2000): Application of systemic experimental procedure to develop a microbial model for rapid fish shelf life predictions. Int. J. Food Microbiol. 60(2-3): 171-184.

Krieg N R and Holt J G (1984):Bergey's Manual of Systematic Bacteriology. Vol. (1) Williams \& Wilkins Baltimore.

Kvenberg, E.J. (1991): Non-indigenous bacterial pathogen. In: Donn, R., Cameron, H., Van Nostrand, R. (Eds), Microbiology of Marine Food Products, New York, Pp. 263291.

Lennette, E. H.; Balows, A.; Hausler, Wand Traunt, J. (1980). Manual of clinical

Lipp, E.K., Rose, J.B. (1997): The role of seafood in food borne diseases in the United States of America. Rev. Sci.Tech. OIE., 16: 620640.

Løvseth A Loncarevic S and BerdalK G (2004):"Modified multiplex PCR method for detection of pyrogenic exotoxin genes in staphylococcal isolates." J. Clin. Microbiol.42:3869-3872.

Lucky, Z. (1977). Methods for the diagnosis of fish diseases.Ameruno Publishing Co, PVT, Ltd. New Delhi., Bomby, New York.

Mandal SC, Hasan M, Shamsur Rahman M, Manik MH, Mahmud ZH, Sirajul Islam MD (2009): Coliform Bacteria in Nile Tilapia, Oreochromisniloticus of ShrimpGher, Pond and Fish Market. World Journal of Fish and Marine Sciences. 1 (3): 160-166.

Mead, J. F., Alfin-Slater, R. B., Howton, D. R. and Popják, G. (1986): Lipids: Chemistry, Biochemistry and Nutrition, p. 486. New 
York: Plenum Press. Microbiology. Am. Soc. Microbiology Washington.

Mol, S., Erkan, N., Ucok, D. and Tosun, Y. S. (2007):. Effect of psychrophilic bacteria to estimate fish quality. Journal of Muscle Foods 18: 120-128.

Morrison, C.; Comtek, J.; Shun, G. And Zwicker, B. (1981). Microbiology and histopathology of saddle back disease of under yearling Atlantic Salmon. Salmon Solar.

Muniruzzaman, M. and Chowdhury, M.B.R. (2004): Sensitivity of fish pathogenic bacteria to various medical herbs. Bangladesh Journal of Veterinary Medicine. 2(1): 75-82.

O'connell J. (2002): Staphylococcus Barbeque cooks must know about stabhylococcus (staph), in Bibliography of Barbeque Health and Safety-California BBQ Association, California Barbeque Association, Inc. Available at httm//www. Cbbqa.com/ articles Food-Safty / Staphylococcus html.

Olivares-Fuster, O., Klesius, P.H., Evans, J. and Arias, C.R. (2008): Molecular Typing of Streptococcus agalactiae Isolates from Fish. Journal of Fish Diseases, 31, 277283.

Post, G. (1987): Textbook offish health. TFLT Publication, Inc.Lid. 2na Ed., 182 -185.

Quinn P J, Markey B K, Carter M E, Donnelly W J and Leonard F C (2002): Vet. Microbial and Microbial Disease Blackwell Sc. U.K.

Rahman, M. M., Rahman, F., Afroz, F., Yesmin, F., Fatema, K. K., Das, K. K. and Noor, R. (2012): Prevalence of pathogenic bacteria in shrimp amples collected from hatchery, local markets and the shrimp processing plant for export quality frozen shrimp. Bangladesh Journal of Microbiology

Rodricks, E.G. (1991): Indigenous pathogen: Vibrionaceae of microbiology of marine food products, Reinhold, New York, Pp. 285295.

Snowdon, J. A., Cliver, D. O. and Converse, J. C. (1989): Land disposal of mixed human and animal wastes: a review. Waste Managment Research 7: 121-134.

Starutch, D. (1991): Survival of pathogenic microorganisms and parasites in excreta, manure sand sewage sludge. Review of Science and Technology 10 (3): 813-846.

Sujatha, K., Senthilkumar, P., Sangeeta, S.,Gopalakrishnan, M.D. (2011): Isolation of human pathogenic bacteria in two edible fishes, Priacanthushamrurand Megalaspiscordylaat Royapuram waters of Chennai, India. Indian J. Sci. Technol., 4(5): 539541.

Wallace, B. J., Guzewich, J. J., Cambridge, M., Altekruse, S. and Morse, D. L. (1999): Seafood-Associated Disease outbreaks in New York, 1980-1994. American Journal of Preventive Medcine 17 (1): 48-54.

World Health Organization (WHO) (2012):Alzheimers disease: the brain killer. Downloaded from

Yagoub, S.O. (2009): Isolation of Enterobacteria and Pseudomonas species from raw fish sold in fish market in Khartoum State. Journal of 27. Bacteriological Research. 1(7): 85-88.

Zaky, M. M. M. (2009): Occurrence of Antibiotic-Resistant and Plasmid DNA Harbouring Bacterial Pathogens in Stressed Polluted Water Environment of Lake Manzala, Egypt Research Journal of Microbiology. 4 (2): 59-66.

\section{How to cite this article:}

Elham I. Atwa. 2017. Bacteriological study of fish samples collected from different markets in Some Egyptian Governoratesand antimicrobial sensitivity of isolates. Int.J.Curr.Microbiol.App.Sci. 6(5): 2765-2776. doi: https://doi.org/10.20546/ijcmas.2017.605.310 